Jurnal Administrasi Negara

ISSN : 2598-4039 (Online)

ISSN : 2302-2221 (Print)
Andrialius Feraera, Syuryansyah

Public Administration Study Program, Faculty of Social Political and Law Sciences

Serang Raya University

\title{
POLICY ANALYSIS OF AGRICULTURAL MODERENIZATION WITH "BERJAYA" FARMER CARD IN LAMPUNG PROVINCE, 2020
}

\author{
Andrialius Feraera, Syuryansyah \\ Public Administration Study Program, Faculty of Social Political and Law Sciences \\ Serang Raya University
}

Corresponding Author Email: andrialiusferaera@gmail.com

\begin{abstract}
Facing the Agricultural Revolution 4.0 The Lampung Provincial Government is trying to make policy innovations on modernization of agriculture through the berjaya farmer card policy. however, in its implementation this policy faces several obstacles so that it is slow in its implementation. On this basis, this study aims to see how the facts of policies, the value of policies and actions taken by the government are for the success of the Berjaya Farmers Card policy. The method used in this research is descriptive qualitative. The technique of collecting data in this research is by making observations, interviews and documentation. The results show first, the fact that the 2020 farmer card triumphant card has entered the socialization and implementation stages even though the progress tends to be slow. Farmers who have joined this policy are only $0.8 \%$ of the total number of farmers in Lampung. The slow process of implementing this policy is also influenced by several factors, namely human resources, geographical factors, bureaucratic structure and social conditions. Second, the value of this policy is still far from its planned goals. Third, the government needs to take actions including providing massive counseling and assistance to young (farmers millennial), increasing the quantity and quality of policy implementers and widening cooperation with other private parties.
\end{abstract}

Keywords: Berjaya Farmers Card; Agricultural modernization, Policy Analysis

\begin{abstract}
Menghadapi Revolusi Pertanian 4.0 Pemerintah Provinsi Lampung mencoba membuat inovasi kebijakan tentang moderenisasi pertanian melalui kebijakan kartu petani berjaya. akan tetapi dalam pelaksanaannya kebijakan ini menghadapi beberapa kendala sehingga lambat dalam implementasinya. Atas dasar tersebut penelitian ini bertujuan untuk melihat bagaimana fakta, nilai dari kebijakan dan tindakan yang dilakukan pemerintah untuk keberhasilan kebijakan ini. Metode yang digunakan dalam penelitian ini adalah deskriptif kualitatif. Berdasarkan penelitian Di tahun 2020 kebijakan kartu petani berjaya telah masuk pada tahap sosialisasi dan implementasi meskipun progresnya cenderung lambat. Petani yang telah bergabung dalam kebijakan ini hanya $0,8 \%$ dari jumlah petani keseluruhan di Lampung. Lambannya proses implementasi kebijakan ini juga dipengaruhi oleh beberapa faktor yaitu pertama sumber daya manusia, faktor geografis, struktur birokrasi dan kondisi sosial masyarakat. Oleh sebab itu pemerintah perlu mengambil tindakan diantarnya memberikan penyuluhan dan pendampingan secara masif kepada petani usia muda (milenial), meningkatkan kuantitas dan kualitas pelaksana kebijakan dan memperlebar kerjasama dengan pihak swasta lainya.
\end{abstract}

Kata Kunci:, Kartu Petani Berjaya; Moderenisasi pertanian, Analisis Kebijakan 
Jurnal Administrasi Negara

ISSN : 2598-4039 (Online)

ISSN : 2302-2221 (Print)
Andrialius Feraera, Syuryansyah

Public Administration Study Program, Faculty of Social Political and Law Sciences

Serang Raya University

\section{INTRODUCTION}

Indonesia is an agricultural country where the agricultural sector is the main sector in the economy. The vast agricultural expanse and supported by a tropical climate should be able to make Indonesia prevail compared to other countries. The rapid development which is defined as physical development has resulted in a lot of land conversion from the agricultural sector to the industrial sector. This of course will have a big effect on the level of agricultural productivity in Indonesia. Based on the research of the Nielsen Company Institute, it is stated that the decline in the agricultural sector is partly due to the low commitment of government policies at each period in supporting the agricultural sector to become a leading sector (ugm.ac.id: 2020).

Lampung Province is one of the provinces that has a major contribution to the agricultural sector in Indonesia. Approximately $50 \%$ of the total land in Lampung Province is in the agricultural sector. As an area dominated by the agricultural sector, Lampung Province is the number 1 cassava producer in Indonesia. Apart from cassava, Lampung is also the national number 2 producer of sugarcane, corn No.3 and rice number 7 nationally. The economic structure of Lampung Province in the first quarter of 2020 was also dominated by the agriculture, forestry and fisheries business fields (29.65 percent) and then the processing industry sector (18.83 percent); As well as Wholesaler-Retail Trade and Car-Motorcycle Repair (11.99 Percent) (Document for the Development of Lampung Socio-Economic Macro Indicators for the 1st Quarter of 2020).

Based on the data above, it can be seen the importance of the agricultural sector in Lampung Province in driving the economy. Although basically there is a tendency of decreasing every year in this sector (dinastph.lampungprov. go.id: 2020). This shows that there is a shift in community activities from the agricultural sector to other sectors. In addition, the agricultural sector is also not without problems. The availability of fertilizers, the availability of seeds, inadequate social and educational conditions, the weak competitiveness of commodities to the marketing of the harvest are still serious problems and must be faced and resolved by all parties, especially local governments. 
Jurnal Administrasi Negara

ISSN : 2598-4039 (Online)

ISSN : 2302-2221 (Print)
Andrialius Feraera, Syuryansyah

Public Administration Study Program, Faculty of Social Political and Law Sciences

Serang Raya University

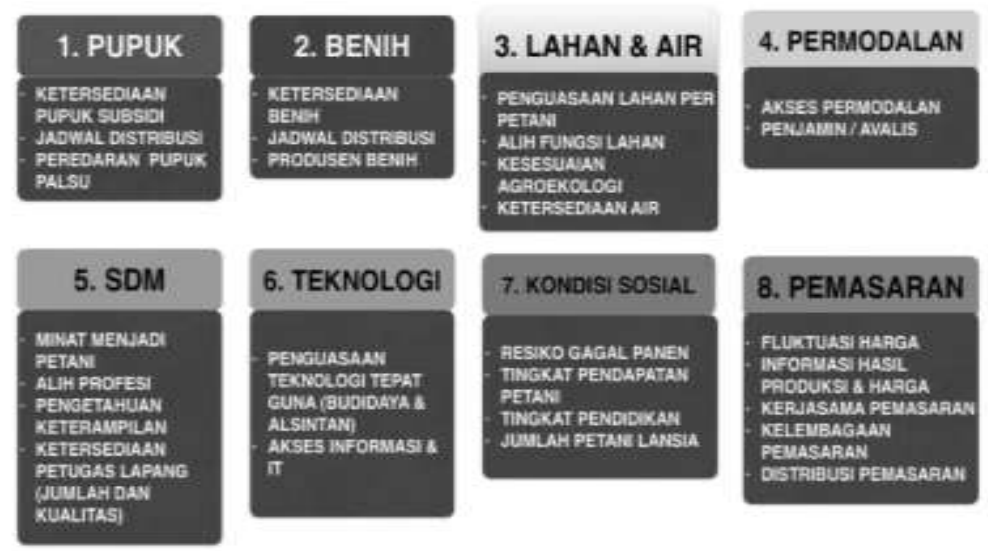

Figure 1. Agricultural Problems in Lampung Province Results of the FGDs for the Berjaya Farmer Card Program

Source: Results of FGDs for the Lampung Province of Berjaya Farmer Card Program

Furthermore, there are contemporary problems facing the agricultural sector where modernization and rapid technological leaps have given birth to new patterns in society. The agricultural revolution 4.0 tries to take advantage of digital technology in agriculture that is oriented towards Smart Farming, Measured Agriculture (Precision Farming) and Bio Technology (Gene Editing). The agricultural revolution 4.0 will not only affect producers, but will also bring consumers closer to farmers or agricultural companies.

Responding to these problems, the Lampung Provincial Government in 2020 created a policy innovation to make farmers in Lampung Province better prepared to respond to the 4.0 agricultural revolution. The Lampung
Provincial Government issued a Berjaya Farmers Card Program which is supported by an android and web-based application. This program is temporarily still focused on farmers who are members of farmer groups. The aim of this program is to make it easier for farmers to access agricultural information, provide agricultural facilities to sell agricultural products.

Based on preliminary analysis in the field, this program tends to be slow to implement considering that this program has been planned since 2019 and only at the end of 2020 can be implemented. So far, the peasant card policy has only been implemented in four districts in Lampung, namely Central Lampung Regency, Pringsewu Regency, North Lampung Regency, Pesawaran. Furthermore, the obstacles faced by this 
Jurnal Administrasi Negara

ISSN : 2598-4039 (Online)

ISSN : 2302-2221 (Print)
Andrialius Feraera, Syuryansyah

Public Administration Study Program, Faculty of Social Political and Law Sciences

Serang Raya University program are first, the average farmer is quite old and finds it difficult to run the internet, moreover, not all farmers have an Android phone. Third, the large number of farmers in Lampung Province takes a long time to collect data. Fourth, it is difficult to persuade market players to shift from traditional to digital ways.

Basically, policy is a government activity to solve problems in society either directly or through various institutions that affect people's lives (Woll in Tangkilisan, 2003: 2). Through this successful farmer card application, farmers can connect directly not only to the government but also to:

1) Distributor of seeds, fertilizers and medicines so that farmers are expected to get convenience and cheaper prices.

2) Buyers, farmers can sell their crops directly to buyers without having to go through an agent.

3) Kiosk Agricultural production facilities.

4) Farmer Group

5) Financial Institutions (Banking)

6) Agricultural

(instructorwww.kpb.lampungprov. go.id: 2020).

Therefore, there is a need for public policy analysis to see the extent to which this policy has been implemented and to what extent the value applied has been achieved. Apart from looking at facts, policy analysis also seeks to produce information about the values and a series of selected actions. Policy analysis also includes evaluation and policy recommendations. This policy analysis will answer three questions:

1) A value whose achievement is the main yardstick for assessing whether a problem has been resolved?

2) Facts whose existence can limit or enhance the attainment of values?

3) Actions whose implementation can lead to the achievement of values? (Dunn, 2003: 97).

These questions can be analyzed using empirical, evaluative and normative approaches or can use a combination of the three approaches. The empirical approach answers the fact questions about current conditions and problems and the effect on the achievement of the value of the information generated is descriptive. In contrast, the evaluative approach is emphasized to answer questions of value. The value in question is about the benchmark for the resolution of a problem, the information produced is evaluative. The normative approach is emphasized on the recommendation of a series of future actions that can solve public problems (Dunn, 2003: 97-98). 
Jurnal Administrasi Negara

ISSN : 2598-4039 (Online)

ISSN : 2302-2221 (Print)
Andrialius Feraera, Syuryansyah

Public Administration Study Program, Faculty of Social Political and Law Sciences

Serang Raya University
Based on the problems described above, it encourages researchers to conduct a study with the title: Analysis of Agricultural Modernization Policy Analysis with Berjaya Farmers Card in Lampung Province in 2020. The purpose of this research is to first see how the facts are in achieving of berjaya farmer card?. Second, Seeing the value achieved from the policy of modernizing agriculture with berjaya farmer card? Third, what are the actions that have been taken to achieve the value of the policy of modernizing agriculture with berjaya farmer card.

\section{METHODOLOGY}

This research uses descriptive qualitative analytical approach. The purpose of this descriptive research is to make descriptions, descriptions or paintings systematically and the relationships between the phenomena being investigated (Nazir, 2011: 52). In this case the researcher only takes pictures of what happens to the object or area under study, then describes what happened in the form of a straightforward research report (Arikunto, 2010: 3). This research was conducted in Lampung Province to be precise with the farmers who received the Berjaya farmer card. The time of this research was carried out in 2020.
The data collection technique in this study was to make observations, interviews and documentation. Determination of informants was carried out purposively, which was carried out in accordance with the research needs, including the Lampung Provincial Government and Farmers who received the Berjaya Farmers Card in Pringsewu and Central Lampung District. Furthermore, the documentation was obtained from data including the CDE program blueprint, the results of the FGD on agricultural problems in Lampung and data from the Berjaya farmer card application. The data analysis technique used is three streams of activity that occur simultaneously, namely data reduction, data presentation, drawing conclusions or verification (Miles and Huberman, 1996: 16). In order to obtain valid data, data triangulation was carried out by checking the correctness of information in the field (Moleong, 2007: 330).

\section{FINDING AND DISCUSSION}

Facts in the Achievement of Value about the Berjaya farmer card in Lampung Province

Facts are circumstances or events that are reality or something that is empirically true and can be supported by provisional evidence or it could be an opinion that comes from a belief which 
Jurnal Administrasi Negara

ISSN : 2598-4039 (Online)

ISSN : 2302-2221 (Print)
Andrialius Feraera, Syuryansyah

Public Administration Study Program, Faculty of Social Political and Law Sciences

Serang Raya University may be supported by some evidence. From facts and events in the field, it can be seen to what extent this policy has achieved its objectives and the extent to which benefits received by policy recipients. Furthermore, the results of these policy facts can be used as evaluation material to improve further policies.

Basically, the Peasants Card policy is a policy renewal from the previous policy, namely the farmer card. The farmer card is a program of the Ministry of Agriculture to regulate the supply of fertilizers for farmers in Indonesia. Based on the Guidelines for the Implementation of the Provision and Distribution of Subsidized Fertilizer for the Year 2018 issued by the Ministry of Agriculture of the Republic of Indonesia in 2017, subsidized fertilizer is an item under supervision whose procurement and distribution is subsidized by the Government for the needs of farmer groups and / or farmers in the agricultural sector. Based on the Guidelines for the Provision of Subsidized Fertilizer in 2018, there are five types of subsidized fertilizers allocated to the community, namely urea, sp 36, za, npk, and organic.

The farmer card only focuses on the distribution of subsidized fertilizers from the government to farmers. In practice, the farmer card policy faces obstacles starting from the social conditions of the community, resources and conditions of implementing agents (Mutiara, Diah: 2019). At the beginning of its implementation, this farmer card also received rejection from farmers considering that farmers did not understand complicated technology and processes.

"Now, you have to have an account and transfer money first to an ATM. So farmers who are old and clueless about the hassle of applying the farming card. Currently, there are still those who have not received a farming card. Even though some have obtained it, they cannot use it "(Radarkudus.jawapos.com:2018)

Berjaya farmer card is a renewal model for the farmer card policy. berjaya farmer card has a more complex system than the farmer card. The victorious farmer card is an agricultural system management in Lampung based on Mobile Apps, Web Apps, and QR Code, and agricultural automation tools. This application involves farmers, Gapoktan, Bumdes, industries which are fully managed by the local government of Lampung Province. Farmers as card holders are entitled to the facilities provided to improve the welfare of farmers and farmer families. In addition 
Jurnal Administrasi Negara

ISSN : 2598-4039 (Online)

ISSN : 2302-2221 (Print)
Andrialius Feraera, Syuryansyah

Public Administration Study Program, Faculty of Social Political and Law Sciences Serang Raya University to data on main agricultural actors, this card also contains data on subsidized fertilizer needs, irrigation route data and irrigation schedules, 2020 data) Lampung province planting calendar, data on agricultural production facilities, harvest data and distribution data for subsidized fertilizers (Blueprint Project of Berjaya farmer card).

The path that must be followed for farmers who join the Berjaya Farmers Card is. First, farmers provide nonelectronic data in the form of name, address, ID card number, place of birth, cellphone number, land address, land area, land ownership status, land commodity, agricultural group. Second, provide complete member data to extension workers. Third, the data validation instructor and input data through the system. Fourth, the TPH Office verifies the data and stores valid data in the farmer database. Fifth, the farmer database will be integrated with all data in the data center. Sixth, Data Farmers will integrate data with the agricultural extension management information system application owned by the Ministry of Agriculture.

Table 1. The 2020 Berjaya Farmer Card Activity Plan

\begin{tabular}{llc}
\hline No & \multicolumn{1}{c}{ Activity } & \multicolumn{1}{c}{ Month } \\
\hline 1 & $\begin{array}{l}\text { Preparation of a work team divided into a development } \\
\text { team and a system policy team }\end{array}$ & January \\
2 & Analysis of system requirements & February \\
3 & Making a system design based on UML diagram & March \\
4 & Concept and discussion of system design in the blueprint & March \\
5 & $\begin{array}{l}\text { System survey, system analysis, system design, System } \\
\text { creation, system implementation, system maintenance. }\end{array}$ & April-October \\
6 & $\begin{array}{l}\text { Farmer Dashboard, website-based, Apps and SMS } \\
\text { Gateway }\end{array}$ & Scholarship Integration \\
8 & KUR Integration & July-December \\
\hline
\end{tabular}

Source: Blueprint of Berjaya farmer card 
Jurnal Administrasi Negara

ISSN : 2598-4039 (Online)

ISSN : 2302-2221 (Print)
Andrialius Feraera, Syuryansyah

Public Administration Study Program, Faculty of Social Political and Law Sciences

Serang Raya University
Based on the table, the implementation of the berjaya farmer card policy began in January 2020. Starting with the preparation of a work team that became the development team and the system policy team. The Lampung provincial government is the leading sector in policy in coordination with the Lampung Provincial and District Agriculture Offices. In addition, the provincial government is also working with other parties, namely banks as credit channeling institutions for farmers, namely Bank BNI. The successful farmer card application system that is meant is a Web-based application and is ready for use in 2020. This application can be accessed at https://www.kpb.lampungprov.go.id/ and Android which can be downloaded on the play store In this application there is a menu for farmers and non-farmers, including market players.

Next is the implementation stage where this stage is the most important stage in a policy. The success of the policy really depends on how it is implemented in the field. No matter how good a policy plan is, it will not be of any benefit if it is not implemented. The importance of implementing this policy is also emphasized by the opinion of Udoji in Agustino (2006: 154) that: "The execution of policies is as important if not more important than policy making. Policy will remain dreams or blue prints jackets unless they are implemented ".

Based on facts in the field, Berjaya farmer card in Lampung Province in 2020 has entered the socialization and implementation stages. Although the progress in implementation tends to be slow. This successful farmer card policy was just launched in October 2020 in Trimurjo District, Central Lampung Regency. This month, the farmer cards were successfully socialized and implemented in Pringsewu District, to be precise, Banyumas District and two other districts, namely North Lampung and Pesawaran. Currently 7,235 farmers have registered via online identification numbers. While the number of farmers in Lampung is 840,000 Farmers (Radarlampung.co.id: 2019). This shows that only 0.86 percent of registered farmers out of the total number of farmers in Lampung Province.

In the first phase of 2020, the Lampung provincial government in collaboration with BNI Bank has issued 2000 cards out of the target of 14,000 berjaya farmer card. This number is very far from the planning target where the target of farmers who get berjaya farmer card is 200,000 farmers. This is based on a statement from the Chief Executive of Berjaya farmer card) M. Yusuf Barusman who said that: 
Jurnal Administrasi Negara

ISSN : 2598-4039 (Online)

ISSN : 2302-2221 (Print)
Andrialius Feraera, Syuryansyah

Public Administration Study Program, Faculty of Social Political and Law Sciences

Serang Raya University
"Our data has been collected from various parties, now $50 \%$ of the data has been entered, we just need to verify it. The initial stage, perhaps 200 thousand farmers can get this Berjaya Farmers Card. But it also depends on the readiness of the location (Radarlampung. co.id: 2019)

The slow implementation of this successful farmer card policy is also influenced by the following factors:

\section{Human Resources Human}

Resources in this case are the resources for implementing policies and resources for policy recipients. The resources for implementing the policy are the Lampung Provincial Government and stakeholder partners and stakeholders under it up to the agricultural extension agents in the village. This agricultural instructor has a very important role in disseminating the successful farmer card policy. In fact, Lampung Province currently does not have the ideal number of agricultural extension agents with 2656 villages (Data from BPS Lampung: 2010). Lampung Province has 1212 agricultural extension workers consisting of 713 civil servants, 499 daily freelance workers (THL) spread across 15 districts / cities. Ideally, every village should have 1 agricultural instructor. This means that the Province of Lampung still has a shortage of 1444 agricultural instructors.

Furthermore, the resource for receiving the policy is farmers. Farmers in this case are people who have businesses in agriculture and own agricultural land. Based on the 2018 agricultural census, the number of households that have agricultural businesses in Lampung is 1,340,285 and is dominated by the old age group. Here is the list: 
Jurnal Administrasi Negara

ISSN : 2598-4039 (Online)

ISSN : 2302-2221 (Print)
Andrialius Feraera, Syuryansyah

Public Administration Study Program, Faculty of Social Political and Law Sciences

Serang Raya University

Table 2. Data on the number of agricultural business

households and age groups of household heads.

\begin{tabular}{|c|c|c|}
\hline No & Age Range & Total \\
\hline 1 & $<25$ & 11,665 \\
\hline 2 & $25-35$ & 179,447 \\
\hline 3 & $36-54$ & 717,548 \\
\hline 4 & $55-64$ & 256,646 \\
\hline 5 & $\geq 65$ & 174,979 \\
\hline & Total & $\mathbf{1 , 3 4 0 , 2 8 5}$ \\
\hline
\end{tabular}

Source: Agricultural survey data for 2018 Indonesian Central Bureau of Statistics Pages 23-24.

Based on the table, the largest age group that is a farmer is the age group over 40 years. As many as $50.5 \%$ of the farmers were aged $35-54$ years and $32.2 \%$ were over 55 years old (processed by researchers). This shows that the majority of the resources for receiving this policy are the old age group. Based on the fact that farmer groups in old age are not familiar with technology, especially web and android based applications. This of course will complicate the process of implementing the successful farmer card policy.

\section{Geographical}

The geographical conditions of Lampung Province, which have many hills, rivers and beaches, such as West
Lampung, Tanggamus, East Lampung and Mesuji districts, have made several areas in Lampung not yet have good internet access. Agricultural systems with the basic web system and android such as this victorious farmer card are very dependent on good internet access. Without internet access, farmers cannot access the agricultural information provided in the KPB.

Furthermore, the Provincial Government is currently working with only one bank, namely Bank BNI and Bank BNI, which are only located in the district capital. This means that if farmers want to access capital or save, they have to go to the district capital, which is quite far from the village. Currently berjaya farmer card is still being tested in sub- 
Jurnal Administrasi Negara

ISSN : 2598-4039 (Online)

ISSN : 2302-2221 (Print)
Andrialius Feraera, Syuryansyah

Public Administration Study Program, Faculty of Social Political and Law Sciences

Serang Raya University districts close to the regency capital, for example Trimurjo sub-district which is close to Metro City, while other subdistricts such as Bandar Surabaya District Central Lampung Regency have a distance of $80 \mathrm{~km}$ and must be traveled within 2 and a half hours to the district capital of Lampung Middle. This of course will affect the implementation of the Berjaya Farmers Card.

\section{Bureaucratic Structure}

Basically, to become a member of this successful farmer card (KPB) is quite easy, namely submitting personal data and land ownership data through the Farmer Group Association. Then, farmers can access the application from anywhere because the application is based on android and web. The problem is that not all farmers are members of farmer group association, so farmers who do not join farmer group association can only get applications other than farmers on the Berjaya Farmers Card web.

\section{Socio-Cultural}

The community's traditional farming habits where they sell their crops to collectors are still difficult to change, especially with the online trading system through the application. The existence of an agricultural system by borrowing capital from middlemen is also the reason farmers have to sell their crops to these middlemen. Furthermore, there is a mindset that when the government asks for farmer data, they think they will get help from the government. This requires expertise and good communication patterns from the government to farmers. The condition of the Covid 19 Pandemic, which has not ended in 2020, also made it difficult for the government to disseminate policies. It is feared that socialization involving many people will become a new cluster in the spread of Covid 19.

\section{Value Achieved in Government Policy on Berjaya Farmers Card in Lampung Province.}

Policy values are made on the basis of public interest or morally accountable policies (Anderson: 2006). The value achieved from this policy refers to the achievement results of this Berjaya Farmers Card policy. So it can be seen whether the objectives of this policy have been achieved or not. This successful farmer card (KPB) has the first objective, to make farming more efficient, resulting in efficiency, increased productivity and competitiveness. Second, measurable agriculture. Third, smart agriculture (Fast, Efficient, Economical). Fourth, Standardization of Agricultural Commodities. Fifth: Guarantee information on the availability of 
Jurnal Administrasi Negara

ISSN : 2598-4039 (Online)

ISSN : 2302-2221 (Print)
Andrialius Feraera, Syuryansyah

Public Administration Study Program, Faculty of Social Political and Law Sciences

Serang Raya University agricultural production facilities (fertilizers, seeds, etc.).

Based on the facts on the ground, the implementation of Berjaya Farmers Card policy in the first year is still far from achieving the overall policy objectives. In this first year, the new policy was tested in several areas in Lampung. The number of farmer cards that have been issued by BNI bank is still far from the target. The most obvious value achievement in this first year was the improvement of farmer data based on data collection and farmer data input. The Lampung Provincial Government has valid data related to farmer personal data and farming business data.

However, farmers who have received a victorious farmer card can enjoy web and Android-based applications in which there is a planting calendar and information related to agriculture. In this first year, farmers who have joined the successful farmer card can enjoy the KUR program and the cooperating bank, namely BNI, on a predetermined condition.

\section{Actions in Achieving Government Policy Regarding Berjaya Farmers Card in Lampung Province.}

The shift in the agricultural system in response to the 4.0 agricultural revolution basically has not been able to be widely accepted by farmers.
According to Kilmanun and Astuti (2020), the obstacles to the 4.0 agricultural revolution are, first, the need to improve infrastructure, costs and farmers who are not literate technologically. However, the arrival of this agricultural revolution could not be stopped. As a result, farmers must be forcefully modernized in terms of agricultural management. Many farmers in Lampung Province still choose to use traditional farming systems as opposed to sophisticated technological equipment. Apart from limited costs, limited knowledge is also a factor that hinders the pace of technology to penetrate the agricultural sector in Lampung Province.

The role of the Lampung Provincial Government and its staff is needed to make agriculture in Lampung Province more modern. In order to achieve the policy objectives of the Berjaya Farmers Card, the Government must be faster and more massive in disseminating information to farmers during the Covid 19 pandemic. Farmers must be provided with sufficient education regarding this Berjaya Farmers Card. This berjaya farmer card policy has very good objectives, therefore the biggest challenge is how to convince farmers to join this KPB.

The number of agricultural extension agents in the village should be increased considering that the number of 
Jurnal Administrasi Negara

ISSN : 2598-4039 (Online)

ISSN : 2302-2221 (Print)
Andrialius Feraera, Syuryansyah

Public Administration Study Program, Faculty of Social Political and Law Sciences

Serang Raya University extension workers and villages in Lampung Province is not yet ideal. The emergence of Law 23/2014 on Regional Government basically strengthens the institutions of agricultural extension agents in the regions so that the existence of agricultural extension agents can be improved (Vintarno, Suprayogi, Adiwisastra: 2019).

The majority of people in Lampung are farmers, therefore it needs a more massive approach from the Lampung provincial government in terms of agricultural extension. However, the issue of budget and appointment is also not an easy problem to solve. The strength of the Lampung Province APBD will not be able to bear the salaries of employees if the amount is added. Therefore, the Lampung provincial government needs to find a way out of the problem of the lack of extension workers in the field so that this policy can run according to the expected objectives.

The Lampung Provincial Government must also provide and ensure facilities and infrastructure to support the achievement of the objectives of this policy. The habit of the community, especially coffee and pepper farmers, staying in the garden during the treatment and harvesting process makes them far from internet access so that it will be difficult to accept this policy. Therefore, the government needs to ensure that every area in Lampung Province has good internet access because this policy is very dependent on internet access.

The Lampung Provincial Government needs to develop cooperation not only with BNI Bank considering that BNI Bank has not yet entered rural areas. Remote access to the district capital makes people lazy and not all people have a vehicle. Provincial governments need to work with banks that are able to reach and be reached by farmers easily.

Furthermore, increasing the role of youth or millennials in agriculture also needs attention. Based on the facts in the previous discussion, the majority of farmers are old age. Old generation farmers are not familiar with the internet, so it will be difficult if forced to apply to old age farmers. Provincial government should focus on young farmers. The millennial usually more interested in working in the industry or other sectors outside of agriculture. There is a need for a community of young entrepreneurs in the agricultural sector. This community is necessary to increase the confidence of young people in farming. The nature of the generation millennial who likes to create communities and take advantage of communication tools must be implemented through the support of the 
Jurnal Administrasi Negara

ISSN : 2598-4039 (Online)

ISSN : 2302-2221 (Print)
Andrialius Feraera, Syuryansyah

Public Administration Study Program, Faculty of Social Political and Law Sciences

Serang Raya University government and stakeholders (Yofdiattinda: 2018).

The agricultural sector in Lampung has to make many leaps of innovation. Progress and modernization in the agricultural sector can occur if farmers are responsive to change. The current fast movement of technology really needs to be captured and initiated by agricultural sector actors who have entered the Agricultural Revolution 4.0. The agricultural sector is also encouraged to adopt this technological revolution.

\section{CONCLUSION}

Based on the results of an analysis of the policy of modernizing agriculture through the triumphant farmer card in Lampung Province, it can be concluded that:

\section{Facts}

In 2020 the successful of berjaya farmer card policy has entered the socialization and implementation stages even though the progress tends to be slow. This successful farmer card has just been tested in four districts in Lampung. The number of farmers who have been listed on the farmer victorious card in 2020 is only 72335 or 0.86 percent of the total number of farmers in Lampung Province. Even though it has been registered, facts in the field show that not all registered farmers are active in the web-based or android-based farmer card application.

The slowness of the policy implementation process is also influenced by several factors, namely human resources. The number of extension workers that is not ideal with the number of villages and the majority of farmers are in old age is a fact that occurs in the field. Second: there are regions that have not received good internet access and are long distances to the district capital to access banking. Third: Farmers who are entitled to receive berjaya farmer card are farmers who are members of Gapoktan, while many farmers in Lampung are not members of Gapoktan. Fourth: The social conditions of the people who are accustomed to traditional agriculture make it difficult for the government to conduct socialization.

\section{Value}

Based on the facts in the field the implementation of the Berjaya Farmers Card policy in the first year is still far from achieving the overall policy objectives. The most obvious value achievement in this first year was the improvement of farmer data based on data collection and farmer data input. However, for farmers who have received a successful farmer card, they can enjoy web-based and android-based 
Jurnal Administrasi Negara

ISSN : 2598-4039 (Online)

ISSN : 2302-2221 (Print)
Andrialius Feraera, Syuryansyah

Public Administration Study Program, Faculty of Social Political and Law Sciences

Serang Raya University applications in which there is a planting calendar and information related to agriculture including banking access.

\section{Action}

The action that must be taken by the Lampung provincial government in achieving the objectives of this berjaya farmer card policy is to provide massive counseling to farmers and assistance, especially to young farmers. Young farmers will find it easier to provide knowledge because young farmers (millennial) are more familiar with Android and the web system. The need to add agricultural extension agents who are equipped with good knowledge about CDE will also facilitate the process of implementing the CDE policy. Furthermore, the importance of convincing farmers that this agricultural modernization has added value that is better than traditional agriculture.

The presence of the 4.0 agricultural revolution cannot be stopped and all parties must accept it, including farmers. Therefore, the government has provided a leap of innovation in the agricultural sector in Lampung Province. This innovation leap needs to be captured and initiated by agricultural sector actors in an effort to face the agricultural revolution. The Victorious Farmers Card has great benefits for farmers, but the government cannot run well without the presence of the farmers themselves. Therefore, farmers need to open the mindset that agricultural modernization will provide added value compared to traditional agriculture. Therefore it is necessary to have good cooperation between the government and farmers, including the private sector. 
Jurnal Administrasi Negara

ISSN : 2598-4039 (Online)

ISSN : 2302-2221 (Print)
Andrialius Feraera, Syuryansyah

Public Administration Study Program, Faculty of Social Political and Law Sciences Serang Raya University

\section{REFERENCES}

Anderson, JE, 2006. Public Policy Making: An Introduction, Boston: Houghton Mifflin Company.

\section{Arikunto, S. 2010. Prosedur Penelitian} Suatu Pendekatan Praktik. Jakarta: Rineka Cipta.

Dunn, William N. 2003. Pengantar Analisis Kebijakan Publik. Yogyakarta: UGM Press.

Kilmanun dan Astuti (2020) "Potensi dan kendala revolusi industri 4.0. Di sektor pertanian". Balai Pengkajian Teknologi Pertanian Kalimantan Barat dan Balai Pengkajian Teknologi Jawa Timur.

Latifa Ashari, Mutiara., Hariani,Dyah. "Analisis Efektivitas Program Kartu Tani Di Kecamatan Banjarnegara Kabupaten Banjarnegara", Jurnal Departemen Administrasi Publik Fakultas Ilmu Sosial dan Ilmu Politik Universitas Diponegoro.

Miles, Mathew B. dan Michael Huberman. 1996. Qualitative Data Analysis (Second Edition). London. Sage Publications.
Moleong, Lexy J. 2007. Metode Penelitian Kualitatif. Bandung. PT. Remaja Rosdakarya Offset.

Tangkilisan, Hessel Nogi SMSi, Drs, 2003. Kebijakan Publik yang Membumi, Konsep, Strategi dan Kasus. Yogyakarta. Lukman Offset dan YPAPI.

Vintarno, Suprayogi, Adiwisastra. 2019. Perkembangan Penyuluhan Pertanian Dalam Mendukung Pertumbuhan Pertanian Di Indonesia". Jurnal Program Pasca Sarjana Kebijakan Publik Fakultas Ilmu Sosial dan Ilmu Politik Universitas Padjadjaran.

Yodfiatfinda. 2018. "Meningkatkan Minat Generasi Muda di Sektor Pertanian Untuk Mewujudkan Ketahanan Pangan". Karya Ilmuah Peseorangan Program Pendidikan Reguler Angkatan LVII Lembaga Ketahanan Nasional RI.

\section{Website:}

https://dinastph.lampungprov.go.id/det ail-post/sektor-pertaniantumpuan-ekonomi-provinsilampung, diakses pada 20 Oktober 2020. 
Jurnal Administrasi Negara

ISSN : 2598-4039 (Online)

ISSN : 2302-2221 (Print)
Andrialius Feraera, Syuryansyah

Public Administration Study Program, Faculty of Social Political and Law Sciences Serang Raya University https://radarkudus.jawapos.com/read/20

18/04/25/67836/terungkap-inialasan-mengapa-petani-tolakpenggunaan-kartu-tani diakses pada 10 Januari 2021.

https://radarlampung.co.id/2019/08/12/k artu-petani-berjaya-dicobakan-di4-kabupaten/ diakses pada 12 Januari 2020.

https://ugm.ac.id/id/berita/16844-sektorpertanian-menurun-sudahsaatnya-petani-diperhatikan. Diakses pada 20 Oktober 2020. https://www.dinastph.lampungprov.go. id/ diakses pada 12 Januari 2020 https://www.kpb.lampungprov.go.id/ diakses pada 20 oktober 2020

\section{Dokumen:}

Blueprint Project of berjaya farmer card.

Lampung province BPS data for 2020.

Document on the Development of Lampung Socio-Economic Macro Indicators for the 1st Quarter of 2020. 